[Forthcoming, American Economic Review]

\title{
Inflation Persistence and Relative Contracting
}

by

\author{
Steinar Holden \\ Department of Economics \\ University of Oslo \\ Box 1095 Blindern, 0317 Oslo, Norway \\ email: steinar.holden@econ.uio.no \\ homepage: http://folk.uio.no/ sholden/ \\ and \\ John C. Driscoll \\ Federal Reserve Board \\ Mail Stop 75 \\ $20^{\text {th }}$ and Constitution Avenue, NW \\ Washington DC 20551 \\ Email: John Driscoll@alum.mit.edu \\ Homepage: http://www.johncdriscoll.net
}

\begin{abstract}
Macroeconomists have for some time been aware that the New Keynesian Phillips curve, though highly popular in the literature, cannot explain the persistence observed in actual inflation. We argue that one of the more prominent alternative formulations, the Fuhrer and Moore (1995) relative contracting model, is highly problematic. Fuhrer and Moore (1995)'s formulation generates inflation persistence, but this is a consequence of their assuming that workers care about the past real wages of other workers. Making the more reasonable assumption that workers care about the current real wages of other workers, one obtains the standard formulation with no inflation persistence.
\end{abstract}

We are grateful to Olivier Blanchard, Jeff Fuhrer, Kai Leitemo, Asbjørn Rødseth, Øistein Røisland, Lars Svensson, as well as two anonymous referees for helpful comments on previous versions of the paper. However, none bear any responsibility for the content of the paper. Steinar Holden is also grateful to NBER for the hospitality when this paper was written. The views presented are solely those of the authors and do not necessarily represent those of the Federal Reserve Board or its staff

JEL Classification: E31, E3, E5.

Keywords: Inflation persistence 
In an important paper, Fuhrer and Moore (1995) showed that the standard formulation of staggered wage setting due to Taylor (1980) implied price stickiness, but not inflation stickiness. Fuhrer and Moore proposed a new formulation, which they referred to as the relative contracting model, which exhibits persistence in inflation. Fuhrer and Moore then showed that the relative contracting model is consistent with US macroeconomic data for inflation and output, while the standard contracting model of Taylor is resoundingly rejected.

Fuhrer and Moore made an important contribution to the literature by showing the empirical weakness of the Taylor model, and by proposing a simple resolution to the problem with a seemingly reasonable justification. The model they proposed has clear advantages, being a convenient analytical formulation that fits the data. Consequently, it has been widely used in the literature and in popular graduate text books (e.g. Walsh (1998), pp. 224-225, 460-467, 472-474, and Romer (2001) pp. 295-296). Furthermore, the model of the US economy used by Federal Reserve Bank (see Brayton and Tinsley (1996), and Brayton et. al. (1997) for discussions of the model) also has close similarities to the Fuhrer and Moore formulation. However, finding a formulation that is both empirically and theoretically satisfying is harder than what one may infer from Fuhrer and Moore. As a justification for their new model, Fuhrer and Moore argue that agents care about relative real wages, and not about nominal wages. In this note, we will argue that this motivation is misleading. Fuhrer and Moore's model is based on agents caring about the real wages that other workers obtained in the past. If Fuhrer and Moore's model were modified so that workers cared about the contemporaneous real wages of other 
workers, which is arguably the more reasonable assumption, then the model coincides with the standard formulation of Taylor (1980). ${ }^{1}$

\section{The Fuhrer and Moore model}

Consider the two-period framework used by Taylor (1980) and Fuhrer and Moore (1995). Wages are set in contracts lasting for two periods. Contracts are staggered, so that half of the contracts are set in each period. Let $\mathrm{x}_{\mathrm{t}}$ denote the log of the contract wage set in period t. Prices are a constant unit markup over wages so that the log of the price index in period $t, p_{t}$, is the average of the contract wages negotiated in period $t$ and period $t-1$.

(1) $\quad p_{t}=1 / 2\left(x_{t}+x_{t-1}\right)$.

Taylor (1980) assumed that contract wages are set as a average of the lagged and the expected future wage contracts, adjusted for excess demand $\mathrm{y}_{\mathrm{t}}$.

$$
\mathrm{x}_{\mathrm{t}}=1 / 2\left(\mathrm{x}_{\mathrm{t}-1}+\mathrm{E}_{\mathrm{t}} \mathrm{x}_{\mathrm{t}+1}\right)+\mathrm{ky}_{\mathrm{t}} \quad \mathrm{k}>0 .
$$

(2) can be rearranged to

\footnotetext{
${ }^{1}$ This paper is not the first that questions the microfoundations of Fuhrer and Moore (1995); c.f. Roberts (1998) and Taylor (1999). However, their arguments are different from ours. Roberts' criticism is that the model implies agents "are concerned about having a large change in their nominal wage relative to inflation when employment is high. Hence, the Fuhrer and Moore model "slips a derivative" relative to the conventional microeconomics". Taylor argues that the wage should be related to the price level over the full contract period, a point already acknowledged by Fuhrer and Moore in their appendix B.
} 


$$
\Delta \mathrm{x}_{\mathrm{t}}=\mathrm{E}_{\mathrm{t}} \Delta \mathrm{x}_{\mathrm{t}+1}+2 \mathrm{ky}_{\mathrm{t}}
$$

where $\Delta \mathrm{x}_{\mathrm{t}} \equiv \mathrm{x}_{\mathrm{t}}-\mathrm{x}_{\mathrm{t}-1}$. First difference (1) to obtain the rate of inflation as:

$$
\pi_{t} \equiv \Delta p_{t}=\frac{1}{2}\left(\Delta x_{t}+\Delta x_{t-1}\right) .
$$

Substituting out for (3) and (3) lagged in (4), we obtain

$$
\pi_{\mathrm{t}}=\mathrm{E}_{\mathrm{t}} \pi_{\mathrm{t}+1}+\mathrm{k}\left(\mathrm{y}_{\mathrm{t}}+\mathrm{y}_{\mathrm{t}-1}\right)
$$

Thus, as emphasized by Fuhrer and Moore (1995), in the Taylor model any persistence in $\pi_{\mathrm{t}}$ must derive from persistence in $\mathrm{y}_{\mathrm{t}}$. In contrast, Fuhrer and Moore propose a new contracting equation, where agents care about relative real wages:

$$
x_{t}-p_{t}=1 / 2\left(x_{t-1}-p_{t-1}+E_{t}\left(x_{t+1}-p_{t+1}\right)\right)+k_{t} .
$$

Substituting the definition of $x_{t}$ in equation (6) into the price index equation (1), yields

$$
\text { (7) } \quad \pi_{\mathrm{t}}=1 / 2\left(\pi_{\mathrm{t}-1}+\mathrm{E}_{\mathrm{t}} \pi_{\mathrm{t}+1}\right)+(\mathrm{k} / 2)\left(\mathrm{y}_{\mathrm{t}}+\mathrm{y}_{\mathrm{t}-1}\right) \text {. }
$$

Thus, there is persistence in inflation, as lagged inflation enters with a positive coefficient.

To justify their model, Fuhrer and Moore (page 131) argue: "In the relative wage specification, however, agents compare the real value of their wage contracts with the 
real value of wage contracts previously negotiated and still in effect, and with contracts expected to be negotiated over the duration of the contract..." However, this justification is misleading. Presumably, the most natural interpretation of "the real value of wage contracts previously negotiated that are still in effect" is $\mathrm{x}_{\mathrm{t}-1}-\mathrm{p}_{\mathrm{t}}$, i.e. the nominal wages set in the previous period evaluated at current prices. In contrast, according to (6), agents care about $\mathrm{x}_{\mathrm{t}-1}-\mathrm{p}_{\mathrm{t}-1}$, that is, the real wages that the other group of workers had in the previous period.

Much more importantly, however, the assumption implicit in (6) is difficult to defend theoretically. It is not difficult to explain why agents may compare their own real wage with the real wage that other groups obtain at the same time, and many other studies make this assumption (eg V. Bhaskar, 1990). However, it is harder to understand why workers should compare their own real wage with the real wage other groups had last period, in particular without taking into consideration the real wage they had themselves at that point in time.

To explore the consequences of the more reasonable assumption, that workers care about the real wage other groups obtain at the same time, we substitute $\mathrm{x}_{\mathrm{t}-1}-\mathrm{p}_{\mathrm{t}}$ for $\mathrm{x}_{\mathrm{t}-1}-\mathrm{p}_{\mathrm{t}-1}$ in (6). Furthermore, we also make the theoretically preferable assumption that the real wage to be determined is the expected real wage over the contract period, and not the real wage in the first period of the contract period (as also argued by Fuhrer and Moore, 1995, in their appendix B). Thus, we substitute $x_{t}-1 / 2\left(p_{t}+E_{t} p_{t+1}\right)$ for $x_{t}-p_{t}$ on the LHS of $(6)^{2}$, to obtain

\footnotetext{
${ }^{2}$ Retaining $x_{t}-p_{t}$ would not change the conclusion qualitatively.
} 


$$
x_{t}-1 / 2\left(p_{t}+E_{t} p_{t+1}\right)=1 / 2\left(x_{t-1}-p_{t}+E_{t}\left(x_{t+1}-p_{t+1}\right)\right)+k y_{t}
$$

However, it is immediate that the price levels cancel out so that (8) can be simplified to (2), that is, the standard framework of Taylor (1980). Thus, the crucial feature of the model of Fuhrer and Moore is not that agents care about relative real wages; indeed, the standard formulation of Taylor is consistent with that. The crucial feature of the model of Fuhrer and Moore is that agents are assumed to care about the real wages that other groups had in the previous period, which is an assumption that is harder to justify.

The empirical specification of the Fuhrer and Moore model, based on four-quarter contracts and given in their equation (16), does also reduce down to the Taylor formulation, if one makes the same modifications as above: (i) replace the past real wages of other workers with their contemporaneous and (ii) deflate the contract to be set with the expected price level over the entire contract period, rather than only with the price level in the first period. ${ }^{3}$ However, this specification is explained accurately by Fuhrer and Moore on page 141 "Note that we have implicitly defined the real contract price as the difference between the current nominal contract price and the current price

$$
\begin{aligned}
& { }^{3} \text { We then obtain (for notational simplicity, and in line Taylor, 1980, we set the } \\
& \text { weights for all groups of workers, } \mathrm{f}_{\mathrm{i}} \text { in Fuhrer and Moore's notation, to be identical) } \\
& x_{t}-\frac{1}{4}\left(p_{t}+E_{t} \sum_{i=1}^{3} p_{t+i}\right)= \\
& \frac{1}{4}\left[\left(\frac{1}{3} \sum_{i}^{3} x_{t-i}-p_{t}\right)+E_{t}\left(\frac{1}{3}\left(\sum_{i}^{2} x_{t-i}+x_{t+1}\right)-p_{t+1}\right)+E_{t}\left(\frac{1}{3}\left(x_{t-1}+\sum_{i}^{2} x_{t+i}\right)-p_{t+2}\right)+E_{t}\left(\frac{1}{3} \sum_{i}^{3} x_{t+i}-p_{t+3}\right)\right]
\end{aligned}
$$

As is readily observable, the price levels cancel out, so this reduces down to the Taylor

(1980), equation (1): $x_{t}=\frac{1}{12} x_{t-3}+\frac{1}{6} x_{t-2}+\frac{1}{4} x_{t-1}+\frac{1}{4} E_{t} x_{t+1}+\frac{1}{6} E_{t} x_{t+2}+\frac{1}{12} E_{t} x_{t+2}$ 
index, $x_{t}-p_{t} . "$ (in the latter part of the paper, Fuhrer and Moore refer to "contract price" rather than "contract wage").

The empirical specification is referred to as (p 141) "a convenient simplification from the theoretically preferable specification that defines the real contract price as the difference between the nominal contract price and the weighted average of price indexes that are expected to prevail over the life of the contract." This more elaborate specification is laid out in Appendix B, where it is accurately explained. However, again the key source for persistence of the specification is that workers compare their wages to the real contract wages other workers had in previous periods.

\section{Conclusions}

Macroeconomists are faced with a puzzle: As pointed out by Fuhrer and Moore (1995) and Taylor (1999), the standard theoretical formulation of the short run aggregate supply curve seems to be an empirical failure. The standard formulation exhibits stickiness in prices but not in inflation, in contrast with the persistence in actual inflation. A number of alternative formulations have been proposed. We argue that one of the more prominent ones, the Fuhrer and Moore (1995) relative contracting model, is highly problematic. Fuhrer and Moore (1995)'s formulation generates inflation persistence, but this is a consequence of their assuming that workers care about the past real wages of other workers. Once one replaces their formulation with the more reasonable assumption that workers care about the current real wages of other workers, the resulting formulation immediately reduces to the standard formulation with no inflation persistence. 
This leaves open the question of how to generate inflation persistence in contracting models. Recently, several different alternative types of explanations have been proposed. Roberts (1998) and Ball (2000) have suggested models that relax the assumption that expectations are rational. Gali and Gertler (1999) make progress by relating inflation to a measure of marginal costs rather than output. Mankiw and Ricardo Reis (2001) argue that information about macroeconomic conditions diffuses slowly through the economy. In a companion paper (Driscoll and Holden, 2002), we show that inflation persistence may be caused by coordination problems associated with workers being concerned about fair treatment, in the sense that they care disproportionately more about being paid less than other workers than they do about being paid more. 


\section{References}

Ball, Laurence S. (2000). "Near-Rationality and Inflation in Two Monetary Regimes." NBER Working Paper No. 7988.

Bhaskar, V. (1990). "Wage Relatives and the Natural Range of Unemployment." Economic Journal 100, 60-66.

Brayton, Flint and P. Tinsley (eds.) (1996). "A guide to FRB/US. A Macroeconomic Model of the United States". Federal Reserve Board Finance and Economic Discussion Series No. 1996-42.

Brayton, Flint, Andrew Levin, Ralph Tryon and John C. Williams (1997). "The Evolution of Macro Models at the Federal Reserve Board.” Carnegie-Rochester Conference Series on Public Policy 47(1), pp. 43-81.

Calvo, Guillermo A. (1983). "Staggered Prices in a Utility Maximizing Framework". Journal of Monetary Economics 12, pp. 383-398.

Clarida, Richard, Jordi Gali and Mark Gertler (1999). “The Science of Monetary Polic: A New Keynesian Perspective." Journal of Economic Literature, XXXVII(4), pp. 11611707.

Driscoll, John and Steinar Holden (2002). "Coordination, Fair Treatment and Inflation Persistence.” Mimeo, Brown University and University of Oslo.

Fuhrer, Jeffrey and Gerald Moore (1995). "Inflation Persistence." Quarterly Journal of

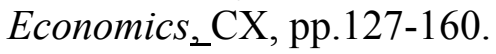

Gali, Jordi and Mark Gertler (1999). "Inflation Dynamics: A Structural Econometric Analysis.” Journal of Monetary Economics 44, 195-222.

Mankiw, N. Gregory and Ricardo Reis (2001). "Sticky Information Versus Sticky Prices: A Proposal to Replace the New Keynesian Phillips Curve." Mimeo, Harvard University.

Romer, David (2001). Advanced Macroeconomics. McGraw-Hill.

Roberts, John (1998). "Inflation Expectations and the Transmission of Monetary Policy." Board of Governors of the Federal Reserve System.

Taylor, John. (1980). “Aggregate Dynamics and Staggered Contracts.” Journal of Political Economy LXXXVIII, pp. 1-24. 
-------------- (1999). “Staggered Wage and Price Setting in Macroeconomics.” Chapter 15 in J. B. Taylor and M. Woodford (eds). Handbook of Macroeconomics. NorthHolland.

Walsh, Carl (1998) Monetary Theory and Policy, Cambridge, MA: The MIT Press. 